\title{
Somatic cell count and chemical composition of milk in naturally BLV-infected cows with different phenotypes of blood leukocyte acid phosphatase
}

\begin{abstract}
Effectiveness of the methods applied to control mastitis is low. Therefore, indices are sought which could improve cow immunity to udder pathogens. The aim of the study was to determine the relationship between the polymorphism of blood leukocyte acid phosphatase (AcP), BLV infection, the somatic cell counts and the milk composition in the first trimester of lactation. Studies were performed on a population of 65 Black-and-White cows, aged 3-6 years, from a leukemia-dominated herd. Enzootic bovine leukemia was diagnosed with ELISA and PCR tests. The following analyses were performed: the contents of total protein, lactose, dry matter, somatic cell count in milk as well as microbiological analyses.

The obtained results indicate the occurrence of an association between a natural BLV-infection and mammary gland secretion disturbances in cows, whereas the relationship with the acid phosphatase polymorphism is not explicit. The obtained results encourage the continuation of studies into the role of blood leukocytes AcP in the pathogenesis of mastitis.
\end{abstract}

Key Words: cattle, virus BLV, udder pathogens, interactions

\section{Zusammenfassung}

Titel der Arbeit: Anzahl somatischer Zellen und chemische Zusammensetzung der Milch bei Kühen mit unterschiedlichen Phänotypen der sauren Phosphatase der weißen Blutkörperchen, die auf natürliche Weise mit dem Virus der bovinen Leukämie infiziert wurden

Die Wirksamkeit der eingesetzten Methoden bei der Bekämpfung von mastitis ist nicht groß. Es wird also nach Koeffizienten gesucht, die hilfreich sein könnten, um die Verbesserung der Widerstandsfähigkeit der Euter gegen die Pathogene zu erreichen. Das Ziel der Untersuchungen lag in der Bestimmung der Abhängigkeiten zwischen dem Polymorphismus der sauren Phosphatase der weißen Blutkörperchen, der BLV Infektion und der Anzahl somatischer Zellen und der Milchzusammensetzung bei Kühen, die sich im ersten Trimester der Laktation befanden. Es wurden 65 Kühe der schwarz-weißen Rasse in einem Alter von 3 bis 6 Jahren der Untersuchung unterzogen, die in einer durch Leukose befallenen Herde standen. Die enzootische Leukose der Tiere wurde anhand der Tests ELISA und PCR diagnostiziert. Es wurden Bestimmungen des Gesamteiweißes, der Laktose, der Trockenmasse, der Anzahl somatischer Zellen in der Milch und mikrobiologische Untersuchungen durchgeführt.

Die erzielten Ergebnisse lassen darauf schließen, dass eine Verbindung zwischen der natürlichen Infektion BLV und den Absonderungsstörungen der Milchdrüse bei den Kühen besteht, während die Abhängigkeit vom Polymorphismus der sauren Phosphatase nicht so eindeutig erscheint. Die erzielten Ergebnisse ermutigen, die Untersuchungen über die Rolle von AcP der weißen Blutkörperchen bei der Pathogenese mastitis fortzusetzen.

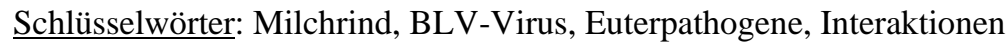

1 . Introduction

The somatic cell count (SCC) in milk indicates the health state of a mammary gland and the inflammation development in an udder is accompanied by an increase in SCC (AMIN et al., 2002). The SCC is associated with mastitis $\left(r_{g}=0.30-0.70\right)$ and its heritability $\left(\mathrm{h}^{2}=0.10-0.14\right)$ is greater than that of clinical cases (IMBAYARWOCHIKOSI et al., 2001). Mastitis is a disease complex which can occur in cows in a 
subclinical form, causing either lower yields and quality of milk or local clinical lesions and milk abnormalities. The costs of animal prevention, diagnostics and treatment make mastitis one of the most costly milk cattle diseases (AMIN, 2001; WELLENBERG et al., 2002). However, the applied methods to control this disease have proven ineffective. Therefore, indices are sought to help improve cow immunity to udder pathogens. Proteins associated with immunological indices may serve as potential markers of mammary gland susceptibility to pathogen infections (DETILLEUX, 2002). Blood leukocyte acid phosphatase (AcP) is considered to be one of them. AcP isoenzymes from cattle blood leukocytes and plasma were first isolated and characterized (ANDREWS and ALICHANIDIS, 1975; ANDREWS, 1976). Four electrophoretic forms of AcP occurring in six phenotype combinations were recorded in Black-and-White cattle (KACZMARCZYK, 1986), however, only one of them exhibits a genetically determined polymorphism (KACZMARCZYK and WALAWSKI, 1992). It is manifested by two phenotypes: A and AB determined by a pair of autosomal alleles. The $A c P^{B}$ dominant allel is responsible for the synthesis of $\mathrm{B}$ isoenzyme occurring in the $\mathrm{AB}$ phenotype. This phenotype is determined by the dominant homozygote and the heterozygote. The $\mathrm{AcP}^{\mathrm{b}}$ recessive allel in the homozygote is manifested by the lack of $\mathrm{B}$ isoenzyme in individuals with the $\mathrm{A}$ phenotype (KACZMARCZYK and WALAWSKI, 1992). Fraction A of the enzyme, recorded in both phenotypes, is not determined by this gene pair. Geneticallydetermined AcP polymorphism in cattle exhibits correlations with the level of some immunological indices (KACZMARCZYK and TAUBE, 1990; KACZMARCZYK et al., 2004; KACZMARCZYK et al., 2005a, 2005b). This indicates the possibility of AcP participation in the immunity processes occurring in a body. Disturbances of these immunological functions may favor pathogenic infections and disease development.

Viral diseases are particularly onerous. Enzootic bovine leukemia (EBL) is a serious problem in cattle breeding. BLV (Bovine Leukemia Virus) which belongs to oncogenic $\mathrm{C}$ type retroviruses is an infectious factor in this disease. The characteristic symptom of this disease is a chronic lymphocytosis which in $2-10 \%$ of animals develops into a nodose form of leukemia and is fatal for an animal. This disease causes significant economic losses and its control is still performed through the elimination of animals infected with BLV or those exhibiting symptoms of the disease. On the other hand, the lack of effective vaccines unables prevention activities. Most often, EBL attacks high yielding cows and activates generally at the final phase of pregnancy or at the beginning of lactation. During the perinatal period the immunological system is not fully ready for defense against pathogens (SHAFER-WEAVER et al., 1996; MALLARD et al., 1998). Mammary gland infections evoking mastitis are also more frequent in this period (BURVENICH et al., 1994).

The presence of the electrophoretic forms of acid phosphatase originating from blood leukocytes in milk from cows with mastitis as well as scarcely researched associations with secretion disturbances in naturally BLV-infected cows encouraged the undertaking of these studies. The aim of the study was to determine the relationship between the blood leukocyte acid phosphatase polymorphism, BLV infection, the somatic cell counts and the milk composition in the first trimester of lactation. 


\section{2. $\quad$ Material and methods}

Studies were performed on the population of 65 Black-and-White cows, aged 3-6 years, from a leukemia-dominated herd. The herd was free from tuberculosis and brucellosis, however it was threatened by mastitis. The cows were fed a balanced energy-protein diet. Diagnoses of enzootic bovine leukemia were confirmed using: the immune-enzymatic ELISA test (Rhône-Poulenc - France), and polymerase chain reaction (PCR). The cows which obtained a positive result in a serological or molecular test were designated as EBL+, while those which obtained a negative result in the three subsequent months under examination, were designated as EBL-. Blood for analyses was sampled from the jugular vein using heparin as an anticoagulant. Milk samples were taken in parallel from all nipples of the udder after draining the initial three spouts. All the analyses were performed in the first, second and third month after calving.

Polymorphism of blood leukocyte acid phosphatase was assayed electrophoretically as described previously (KACZMARCZYK et al., 2004).

\section{1. $\quad$ DNA isolation and PCR reaction}

To isolate genomic DNA, use was made of Wizard Genomic DNA Purification Kit and an isolation procedure provided by the producer (Promega-USA). A fragment of BLV genome with a length of 364 bp located in the area of "gag" 628-1806 bp gene and a fragment of gene of milk kappa-casein (CASK) with a length of 273 bp were amplified from genomic DNA (an indicator of a proper course of PCR reaction). The primers were synthesized at the MWG-Biotech company (Germany), and the following nucleotide sequence was used: leu1: 5'GTCGACAACCTTCCCGACGG3'; leu2: 5’GACAGTCTCGTTTCCAATGG3'; kapp1: 5’GAAATCCCTACCATCAATACC3'; kapp2:

5'CCATCTACGCTAGTTTAGATG3' as well as the previously described PCR procedure (KACZMARCZYK et al., 2004).

\subsection{Somatic cell count, milk composition and microbiological tests}

The analyses of the contents of total protein, lactose, dry matter, somatic cell count in milk as well as microbiological tests were performed in specialist laboratories. Milkoscan, Milkotester and Fossomatic Coulter Counter (Foss-Dania) as well as routine procedures for mammary gland pathogens identification were used. An udder was considered free from infection when the pathogens typical of mastitis were not isolated from the milk obtained from this gland. An udder was considered infected when such microorganisms were isolated from it at least in one of the terms of the analysis.

\subsection{Statistical analysis of data}

The statistical analysis included mean, standard deviation and data distribution conformity test with Gauss curve. In the absence of conformity of the analyzed indices with the normal distribution model, the values of indices analyzed were subjected to logarithmic transformation. A three-factorial analysis of variance (GENERAL ANOVA/MANOVA) was applied. The impact of the following factors was analyzed: blood leukocyte acid phosphatase polymorphism (phenotype A and phenotype $A B$ ), BLV infections (EBL+, EBL-) and month of lactation (I, II, III month of lactation). Moreover, the impact of interactions between these factors on the level of the analyzed 
indices was also examined. Differences between groups were verified with the post hoc test and the Scheffe method. Calculations were made with STATISTICA 6.0 computer software. Moreover, the $\mathrm{chi}^{2}$ test was used to determine the significance of differences between different AcP phenotypes and between the EBL-positive and EBL-negative cows in respect of the incidence of mammary gland infections with mastitis typical pathogens.

\section{Results}

The ELISA and PCR tests applied made it possible to identify 47 EBL-positive cows (72.3\% of population) and 18 EBL-negative cows (27.7\% of population). While analyzing blood leukocyte acid phosphatase polymorphism, the AB phenotype was found in 49 cows (75.4\%), while the A phenotype was found in 16 cows (24.6\%). Within the $\mathrm{AB}$ phenotype cows, 36 animals (73.5\%) were EBL-positive and 13 animals (26.5\%) EBL-negative. Within the A phenotype cows, 11 animals (68.8\%) were EBL-positive and 5 animals (31.2\%) were EBL-negative.

In milk of the cows examined during the first three months of lactation the following mean values were recorded: $762.2 \times 10^{3} / \mathrm{ml}$ somatic cells, $2.88 \%$ protein, $4.41 \%$ lactose and $7.95 \%$ dry matter. Moreover, a wide variety of pathogenic microflora was identified. Microorganisms representing the family of Micrococcaceae (genus: Staphylococcus) (56.4\% of all the isolated microorganisms) and Streptococcaceae (Streptococcus) (35.9\% of all the isolated microorganisms) were the most common. Infections caused by the microorganisms representing the family of Enterobacteriaceae (Escherichia) (2.6\%) and pathogenic fungi from the family of Cryptococcaceae (Candida) (2.6\%) and Aspergillaceae (Aspergillus) (2.6\%) were sporadic. Among the Micrococcaceae bacteria the following were isolated: coagulasenegative Staphylococcus sp., Staphylococcus aureus, $\beta$-hemolyzing Staphylococcus sp. and Staphylococcus saprophiticus, while $\alpha$-hemolyzing Streptococcus sp. and Streptococcus sp. were isolated from the family of Streptococcaceae.

While analyzing the effect of blood leukocyte acid phosphatase polymorphism on the somatic cell count and the milk composition in the experimental cows, no significant difference in the level of these indices was found. Moreover, clearly higher SCC was observed in milk from the AB phenotype cows, although the differences between AcP phenotypes were statistically insignificant (Table 1). However, significant differences in SCC $(\mathrm{P} \leq 0.01)$, the content of lactose $(\mathrm{P} \leq 0.01)$ and dry matter in milk $(\mathrm{P} \leq 0.05)$ between the clinically healthy and leukemic animals (Table 1 ) were recorded. The milk of the EBL-negative cows had lower SCC and higher content of these components than milk of BLV-infected cows. Moreover, a significant interaction between AcP polymorphism and BLV infection in relation to SCC in milk was found (Table 1).

This interaction was manifested by a different pattern of changes of SCC related to the presence of BLV infection (Fig. 1). Thus, in the EBL+ cow milk the significant differences in SCC were found between animals with different phenotypes of acid phosphatase. Higher SCC were found in the milk of the AB phenotype cows than in the milk of the A phenotype animals $(\mathrm{P} \leq 0.001)$ (Fig. 1). 
Table 1

Analysis of the effect of AcP polymorphism, BLV infection and the month of lactation on the somatic cell count and the milk chemical composition in the experimental herd (Analyse des Einflusses des Polymorphismus AcP, der Infektion BLV und des Laktationsmonats auf die Anzahl somatischer Zellen und die chemische Milchzusammensetzung bei der untersuchten Herde)

\begin{tabular}{|c|c|c|c|c|c|c|c|c|c|c|c|c|}
\hline \multirow[t]{2}{*}{ Indices } & \multirow{2}{*}{$\begin{array}{l}\text { Statistical } \\
\text { measures }\end{array}$} & \multicolumn{2}{|c|}{$\begin{array}{c}\text { Phenotypes of } \\
\text { AcP }\end{array}$} & \multicolumn{2}{|c|}{$\begin{array}{c}\text { Result of } \\
\text { diagnostic test }\end{array}$} & \multicolumn{3}{|c|}{ Months after calving } & \multicolumn{4}{|c|}{ Interaction } \\
\hline & & A & $\mathrm{AB}$ & EBL+ & EBL- & $\mathrm{I}$ & II & III & $1 \times 2$ & $1 \times 3$ & $2 \times 3$ & $1 \times 2 \times 3$ \\
\hline \multirow{2}{*}{$\begin{array}{c}\text { SCC } \\
\left(\log _{10}\right)\end{array}$} & $\overline{\mathrm{X}}$ & 2.09 & 2.45 & $2.51^{\mathrm{A}}$ & $1.98^{B}$ & 2.29 & 2.38 & 2.42 & \multirow{2}{*}{$* * *$} & & & \\
\hline & SD & 0.51 & 0.69 & 0.65 & 0.54 & 0.69 & 0.63 & 0.67 & & & & \\
\hline \multirow{2}{*}{$\begin{array}{l}\text { Protein } \\
\text { (\%) }\end{array}$} & $\overline{\mathrm{X}}$ & 2.88 & 2.88 & 2.88 & 2.88 & $2.85^{\mathrm{a}}$ & $2.83^{c}$ & $2.97^{\mathrm{bd}}$ & & & & \\
\hline & SD & 0.28 & 0.25 & 0.26 & 0.25 & 0.21 & 0.27 & 0.27 & & & & \\
\hline \multirow{2}{*}{$\begin{array}{c}\text { Lactose } \\
\text { (\%) }\end{array}$} & $\overline{\mathrm{X}}$ & 4.53 & 4.37 & $4.33^{B}$ & $4.62^{C}$ & 4.45 & 4.42 & 4.36 & & & & \\
\hline & SD & 0.28 & 0.45 & 0.45 & 0.24 & 0.34 & 0.46 & 0.45 & & & & \\
\hline $\begin{array}{c}\text { Dry } \\
\text { matter } \\
\text { fat free }\end{array}$ & $\overline{\mathrm{X}}$ & 8.06 & 7.90 & $7.87^{\mathrm{a}}$ & $8.14^{b}$ & 7.95 & 7.88 & 8.00 & & & & \\
\hline$(\%)$ & SD & 0.41 & 0.51 & 0.50 & 0.40 & 0.39 & 0.51 & 0.54 & & & & \\
\hline
\end{tabular}

Mean values denoted the different of small letter are statistically significant at $\mathrm{P} \leq 0.05$; Mean values denoted the different of capital letter are statistically significant at $\mathrm{P} \leq 0.01 ; 1 \times 2$ : The interaction of AcP polymorphism and result of diagnostic test; *** $\mathrm{P} \leq 0.001$.

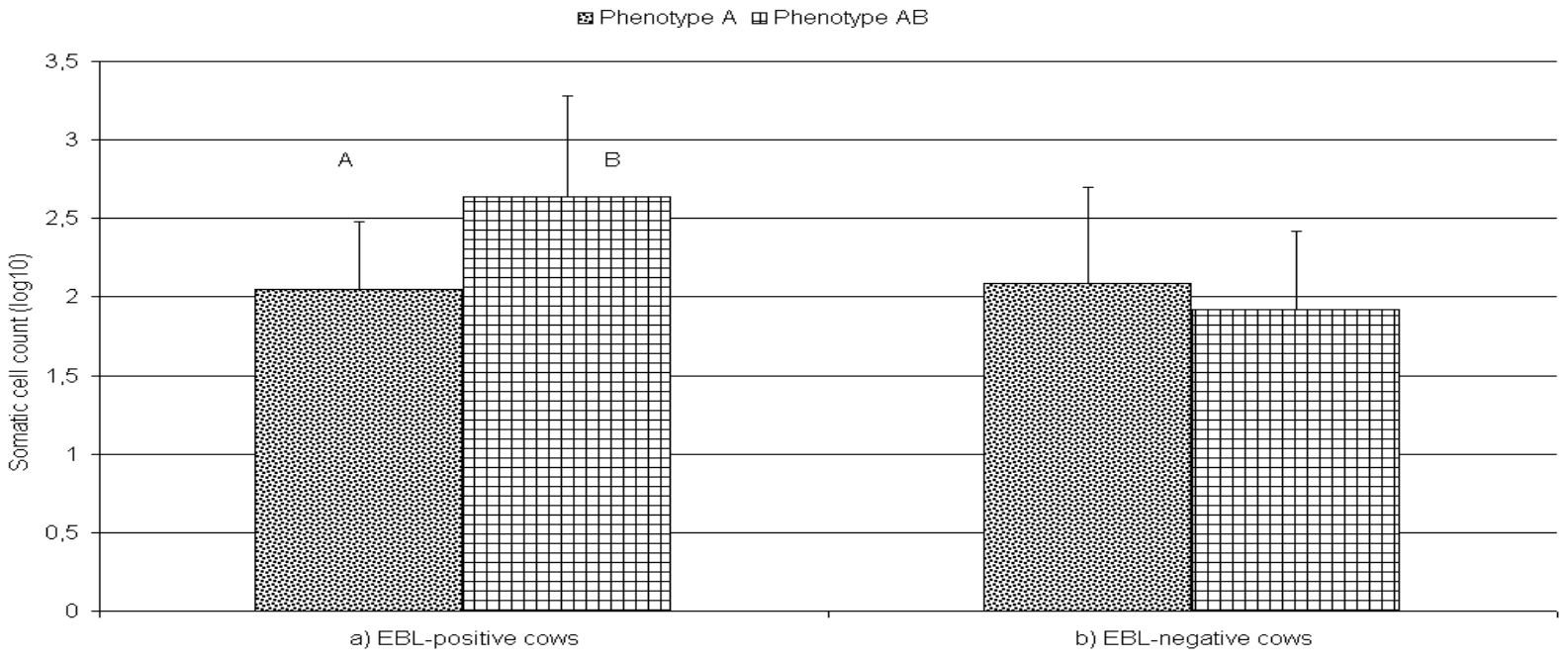

Fig. 1: Somatic cell count (SCC) in milk from cows with different phenotypes of acid phosphatase (Anzahl somatischer Zellen (SCC) in der Milch von Kühen mit unterschiedlichen Phänotypen der sauren Phosphatase) $($ mean \pm SD). Mean values denoted the different of capital letter are statistically significant at $\mathrm{P} \leq 0.001$.

Meanwhile, in the clinically healthy cows these differences were slight and statistically insignificant (Fig. 1). Although the effect of the interaction between AcP polymorphism and BLV infection on the content of lactose and dry matter $(\mathrm{P}=0.07$ and $\mathrm{P}=0.14$, respectively) was insignificant, some differences in the pattern of changes of the analyzed indices related to the AcP polymorphism and health of the experimental animals were found (Fig. 2). Significant differences in the content of lactose $(P \leq 0.01)$ and dry matter $(\mathrm{P} \leq 0.05)$ in milk of the leukemic cows were found between the animals of different acid phosphatase phenotypes. A lower percentage of these components 
was recorded in the $\mathrm{AB}$ phenotype animals than in the A phenotype animals. Meanwhile, in clinically healthy cows, the differences in the level of the analyzed indices were slight and statistically insignificant.

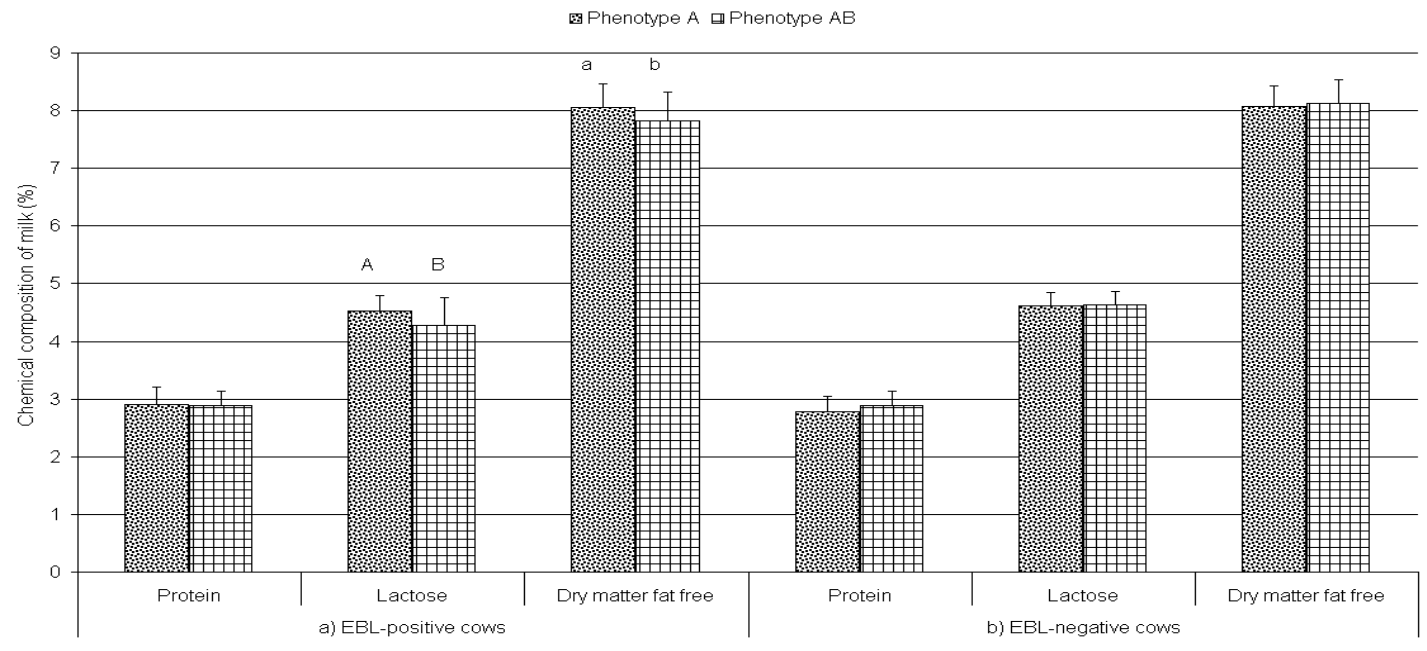

Fig. 2: Composition of milk from cows with different AcP phenotypes naturally BLV-infected and uninfected cows (Milchzusammensetzung von Kühen mit unterschiedlichen Phänotypen AcP, natürlich infiziert und nicht infiziert BLV) (mean \pm SD). Mean values denoted the different of small letter are statistically significant at $\mathrm{P} \leq$ 0.05. Mean values denoted the different of capital letter are statistically significant at $\mathrm{P} \leq 0.01$.

While analyzing the differentiation of SCC and the contents of the particular milk components in the first three months after calving, the only significant differences found $(\mathrm{P} \leq 0.05)$ were in the content of protein (Table 1$)$.

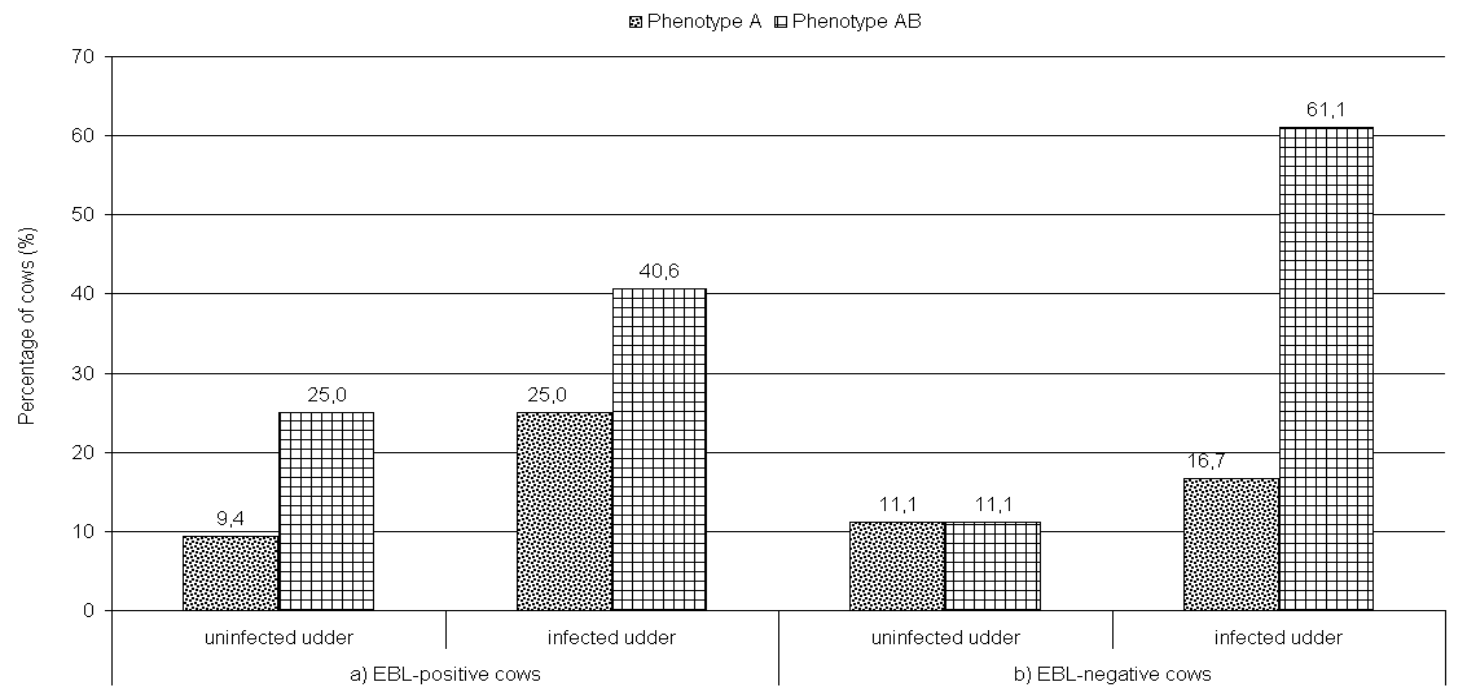

Fig. 3: Acid phosphatase polymorphism and the presence of udder pathogens in EBL+ and EBL- Cows (Polymorphismus der sauren Phosphatase und die Anwesenheit der krankheitserregenden Mikroorganismen der Euter von EBL+ und EBL- Kühen)

The level of this component was lower in the first two months and higher in the third month of lactation. The differences in the levels of the remaining milk components and SCC in the same period were small and statistically insignificant. Figure 3 presents the analysis of the relations between the blood leukocyte acid phosphatase polymorphism, 
EBL infection incidence and mammary gland susceptibility to pathogenic infections. Mastitis-typical microorganisms were more frequently isolated from EBL-positive cows with phenotype $A B$ than from animals with phenotype $A$, however these differences were statistically insignificant (Fig. 3). A considerably greater percentage of udders infected with pathogens was also observed in clinically healthy animals representing the $\mathrm{AB}$ phenotype, however, these differences were statistically insignificant too. The percentage of cows with an udder free from infections among the EBL- cows was the same in both phenotype groups and was slightly greater among the EBL+ cows with the phenotype AB (Fig. 3).

\section{Discussion}

Differences in the somatic cell counts (SCC) in milk from cows with different phenotypes of acid phosphatase were observed in the experimental herd. In the A phenotype animals, the somatic cell count was similar to the SCC found in milk obtained from a healthy udder $\left(232.3 \times 10^{3} / \mathrm{ml}\right)$, while in the AB phenotype animals, the level was a few times higher $\left(935.3 \times 10^{3} / \mathrm{ml}\right)$. However, the observed differences were statistically insignificant. Similar SCC differences between AcP phenotypes were previously recorded in clinically healthy cows from two different herds, however, the differences between the two phenotypes were smaller and statistically insignificant (KACZMARCZYK at al., 1998). These cows also had lower mean SCC, which was determined during entire lactation period for both herds $\left(159.0 \times 10^{3} / \mathrm{ml}\right.$ and $267.6 \mathrm{x}$ $10^{3} / \mathrm{ml}$, respectively).

In the present study, significant $(\mathrm{P} \leq 0.01)$ SCC differences in milk were found between EBL+ and EBL- cows (Table 1). Higher counts of these cells were recorded in the EBL-positive individuals than in EBL-negative cows.

The BLV role in the etiology of mastitis in cattle is still unclear, however the association between viral infection and increased susceptibility to the udder pathogens seems to be very likely (WELLENBERG et al., 2002). BLV molecules were detected near leukocytes in the mammary tissue of BLV antibody positive cows with subclinical mastitis (YOSHIKAWA et al., 1997). Certain mammary gland lesions were observed in these cows in histological examination under an electronic microscope.

The relationship between the BLV infection and the incidence of mammary gland inflammation in cows was studied by many authors but the obtained results are not explicit. Some authors considerably more frequently recorded an increase in SCC in milk and the symptoms of mastitis in cows with enzootic bovine leukemia than in clinically healthy cows (MILOJEVIC et al., 1991; RUSOV et al., 1994). Other authors recorded a significant association between the BLV infection and increased SCC in milk of older cows (EMANUELSON et al., 1992; JACOBS et al., 1995). On the other hand, other authors did not report any differences in SCC in milk and in susceptibility to mastitis between BLV-infected and healthy cows (FETROW and FERRER, 1982; STOTT et al., 1991).

In the present study, significantly greater SCC $(\mathrm{P} \leq 0.01)$ was observed in milk of leukemic cows than in that of healthy cows (Table 1). This indicates an association between the natural BLV infection and SCC in milk.

BLV infection and the development of enzootic bovine leukemia modify the peripheral blood lymphocyte profile. Chronic lymphocytosis in cows is characterized 
by an excessive proliferation of immature $\mathrm{B}$ lymphocytes and a decrease in $\mathrm{T}$ lymphocyte percentage (STONE et al., 1995; WU et al., 1999; KACZMARCZYK et al., 2004). In clinically healthy cows the proportion of these cells is reverse (STOTT et al., 1991; TIZARD, 1992). The lower percentage of $\mathrm{T}$ cytotoxic/supressor lymphocytes (CD8+) recorded in peripheral blood of leukemic cows (STONE et al., 1995; KACZMARCZYK et al., 2004), may favor the BLV infected cells release from the immunological control of the BoLA system. The T CD8+ lymphocytes are able to recognize viral, bacterial or neoplastic antigens presented by BoLA class I molecules and destroy them by secreting cytotoxic substances. The cytokines secreted by lymphocytes activate other cells to synthesize factors destructive to cellular membranes of infected or pathogenic cells (SORDILLO et al., 1995; KIM et al., 1998). Modification of the composition of the T lymphocyte main subpopulations can disturb the functions of the immunological system, favor dissemination of BLV infection in an organism and weaken the mammary gland defensive mechanisms and, as a consequence, contribute to development of inflammation - as manifested by elevated SCC in milk when compared with leukemia-free cows.

In the present experiment, an interaction was found between acid phosphatase polymorphism and leukemia incidence - manifested by a significantly $(\mathrm{P} \leq 0.001)$ greater SCC in milk of leukemic cows with the AB phenotype than in those with the A phenotype (Fig. 1). On the other hand, significant differences between the AcP phenotypes of clinically healthy cows were not recorded. In contrast in the previous studies (KACZMARCZYK et al., 2005b), the A phenotype leukemic cows had significantly higher numbers of neutrophils, lymphocytes and total leukocytes in the blood than the $\mathrm{AB}$ phenotype animals, however, the percentage of these cells in both phenotype groups was very similar. This discrepancy seems to be apparent because the composition of somatic cells in milk is different than the white cell composition occurring in the peripheral blood and the percentage of macrophages, neutrophils and lymphocytes in the mammary gland secretion is modified by physiological (mainly lactation month) and environmental (udder pathogens, etc.) factors (GRUET et al., 2001).

The mean SCC in milk of $762.2 \times 10^{3} / \mathrm{ml}$ recorded in the cows within the first three months after calving indicates a satisfactory sanitary state of the mammary gland. The significantly higher SCC in the AB phenotype EBL-positive cows recorded in the present study seems to be caused by a greater incidence of inflammatory states in them than in the A phenotype cows.

Mastitis is most frequently caused by microorganisms of the Streptococcus (S. agalactiae, S. disagalactiae, S. uberis) and Staphylococcus (S. aureus) which represent the first group of the mammary gland pathogens. They cause greater increases in SCC in milk (HARMON, 1994; SCHEPPERS et al., 1997) than the microorganisms of the second group (HERINGSTAD et al., 2000). In the present study, microorganisms representing the genus Staphylococcus and Streptococcus constituted the most numerous pathogen group. These microorganisms were more frequently isolated from the milk of the $A B$ phenotype EBL-positive cow milk than from that of the A phenotype animals, however, the differences were statistically insignificant (Fig. 3). S. aureus produces endotoxins which enable the pathogen to penetrate the gland tissue and disturb local immunological mechanisms (CIFRIAN et al., 1996). 
The chemical composition of milk from healthy mammary gland of Black-and-White cows is as follows: $3.2 \%$ protein, $4.6 \%$ lactose and $8.7 \%$ fat-free dry matter (BIELAK et al., 1991; PUCHAJDA et al., 1993). Inflammation of mammary gland modifies the chemical composition of milk (HARMON, 1994). The contents of lactose, casein and dry matter decrease. Moreover, the chemical composition, fat dispersion rate and the content of whey proteins are changed.

Lower percentages of total protein and dry matter were recorded in the examined herd. The content of lactose was slightly lower but similar to its average content in milk (Table 1). Lower content of dry matter and lactose in the experimental milk can be caused by certain disease changes in the mammary gland, however, due to their low intensity the decrease in the content of these components is small. The low level of total protein is certainly not associated with the health state of animals but may be caused by the effect of other factors which are presently difficult to precisely define.

Moreover, significant differences in the content of lactose and dry matter between leukemic and clinically healthy cows were found. The contents of these components was lower in EBL-positive than in EBL-negative cows (Table 1). Their content in milk was differentiated by acid phosphatase polymorphism and BLV infection incidence. A significantly lower percentage of these milk components were found in the $A B$ phenotype EBL+ cows than in the A phenotype cows (Fig. 2). The contents of lactose and dry matter in the milk of clinically healthy cows were at the same level regardless of the acid phosphatase phenotype. The values were similar to the average for the breed (4.6\% and $8.1 \%$, respectively). The observed differences in the content of these components among the leukemic cows representing different phenotypes of acid phosphatase seems to be associated with the SCC and the incidence of udder inflammation. The recorded negative correlation between SCC and the content of lactose in milk ( $\mathrm{r}=-\mathrm{0.4}$ ) seems to confirm this suggestion (SAWA and PIWCZYŃSKI, 2002). Moreover, greater SCC was observed in the AB phenotype than in the $A$ phenotype EBL+ cows (Fig. 2). Thus, the lower content of lactose and dry matter in milk from the $A B$ phenotype leukemic cows could result from the more frequent incidence of mammary gland inflammations in these cows than in the A phenotype animals. It could also result from a greater susceptibility of the udder of these cows to pathogens. These microorganisms were more frequently isolated from milk of the AB phenotype EBL+ cows, however, the differences between the two AcP phenotypes were statistically insignificant. The relationship between EBL incidence and an increased SCC in milk seem to indicate the occurrence of an association between BLV infections and susceptibility to mammary gland pathogens, while the recorded correlation with blood leukocyte AcP polymorphism is not explicit and the interpretation of these results can be premature.

Stage of lactation is one of the several factors modifying the milk chemical composition. In the first weeks after calving, the content of total protein in milk is high, then it decreases and for the two subsequent months it is maintained at a low level. An increase in the content of this milk component is observed from the second trimester until the end of lactation (BIELAK et al., 1991; KACZMARCZYK et al., 1998; SAWA and PIWCZYŃSKI, 2002). In the present study, a significantly lower $(\mathrm{P} \leq 0.05)$ content of total protein was recorded in the first two months, while in the third month of lactation an increase in the level of this component was observed (Table 1). Moreover, slight and statistically insignificant differences in the content of lactose 
and fat-free dry matter as well as SCC in milk were found. The quantitative changes in dry matter in milk reported by different authors are not explicit. Some authors (BIELAK et al., 1991; KACZMARCZYK et al., 1998) observed an increase in the content of this component during lactation whereas others reported rather irregular changes (PUCHAJDA et al., 1993). In the secretion of a healthy mammary gland, slight differences were observed in the level of lactose and SCC. A more significant decrease in the content of lactose was recorded as late as in the second half of lactation, while greater SCC was reported at the beginning and at the end of lactation (DELUYKER et al., 1993; KACZMARCZYK et al., 1998). The results of the present study are in line with the general tendency reported by other authors.

The obtained results indicate of an association between a natural BLV-infection and mammary gland secretion disturbances in cows, whereas the relationship with the acid phosphatase polymorphism is not explicit. The obtained results encourage the continuation of studies into the role of blood leukocyte AcP in the pathogenesis of mastitis.

\section{Acknowledgements}

The authors thank Dariusz Kaczmarczyk for his technical assistance in preparing this work print.

AMIN, A.A:

\section{References}

Lactation and sample test-day Multi-trait animal model for genetic evaluation of somatic cell scores in Hungarian Holstein-Friesian crossbreeds. Arch. Tierz., Dummerstorf 44 (2001) 3, 263-275

AMIN, A.; GERE, T.; KISHK, W:

Genetic and environmental relationship among udder conformation traits and mastitis incidence in Holstein Friesian into two different environments. Arch. Tierz., Dummerstorf 45 (2002) 1, 129-138

ANDREWS, A.T.; ALICHANIDIS, E.:

The acid phosphatase of bovine leucocytes, plasma and the milk of healthy and mastitic cows. J. Dairy Res. 42 (1975), 391-400

ANDREWS, A.T.:

Further studies on acid phosphatase of leucocytes origin in normal and mastitic bovine milks. J. Dairy Res. 43 (1976), 127-131

BIELAK, F.; WAWRZYŃCZAK, S.; GWOŹDZIEWICZ, A.:

Changes in milk composition and correlations between milk constituents in consecutive months and lactation periods in the Black-and-White cows. (in polish) Rocz. Nauk. Zoot. 18 (1991), 87-99

BURVENICH, C.; PAAPE, M.J.; HILL, A.W.; GUIDRY, A.J.; MILLER R.H.; HEYNEMAN, R.: KREMER, W.D.J.; BRAND, A.:

Role of the neutrophil leucocyte in the local and systemic reactions during experimentally induced E.coli mastitis in cows immediately after calving. Vet. Quart. 16 (1994), 45-50

CIFRIAN, E.; GUIDRY, A.J.; BRAMLEY, A.J.; NORCROSS, N.L.; BASTIDA-CORCUERA, F.D.: MARQUARDT, W.W.:

Effect of staphylococcal $\beta$ toxin on the cytotoxicity, proliferation and adherence of Staphylococcus aureus to bovine mammary epithelial cells. Vet. Microbiol. 48 (1996), 187-198

DELUYKER, H.A.; GAY, J.M.; WEAVER, L.D.: Interrelationships of somatic cell count mastitis and milk yield in a low somatic cell count herd. J. Dairy Sci. 76 (1993), 3445-3452

DETILLEUX, J.C.:

Genetic factor affecting susceptibility of dairy cows to udder pathogens. Vet. Immunol. Immunopathol. 88 (2002), 103-110

EMANUELSON, U.; SCHERLING, K.; PETTERSON, H.:

Relationships between herd bovine leukemia virus infection status and reproduction, disease incidence, and productivity in Swedish dairy herds. Prev. Vet. Med. 12 (1992), 121-131 
FETROW, J.; FERRER J.F.:

Bovine leukemia virus infection and mastitis.. J. Dairy Sci. 65 (1982), 881-882

GRUET, P.; MAINCENT P.; BERTHELOT X.; KALTSATOS V.:

Bovine mastitis and intramammary drug delivery: review and perspectives. Adv. Drug Delivery Rev. 50, (2001), 245-159

HARMON, R.J.:

Physiology of mastitis and factors affecting somatic cell counts. J. Dairy Sci. 77 (1994), 2103-2112

HERINGSTAD, B.; KLEMETSDAL, G.; RUANE, J.:

Selection for mastitis in dairy cattle: a review with focus on the situation in the Nordic countries. Livest. Prod. Sci. 64 (2000), 95-106

IMBAYARWO-CHIKOSI, E.V.; MAKUZA, ST.M.; WOLLNY, C.B.A.; BANDA, J.W.:

Genetic and phenotypic parameters for individual cow somatic counts in Zimbabwean Holstein-Friesian cattle. Arch. Tierz., Dummerstorf 44 (2001) 2, 129-137

JACOBS, R.M.; POLLARI, F.L.; MCNAB, W.B.: JEFFERSON B.:

A serological survey of bovine syncytial virus in Ontaria: associations with bovine leukemia and immunodeficiency-like viruses, production records, and management practices. Can. J. Vet. Res. 59 (1995), 2701-2708

KACZMARCZYK, E.; BOJAROJĆ, B.; ZABOLEWICZ, T.; WALAWSKI, K.:

Acid phosphatase polymorphism of blood leucocytes versus the yield, composition and properties of milk of black and white cows. (in polish) Acta Acad. Agricult. Tech. Olst. 48 (1998), 23-43

KACZMARCZYK, E.; BOJAROJĆ-NOSOWICZ, B.; FIEDOROWICZ, A.: DEMIANOWICZ W.:

Polymorphism of blood leukocyte acid phoshatase and the profile of peripheral blood lymphocytes in the first of lactation trimester of cows naturally-infected with bovine leukemia virus. Arch. Tierz., Dummerstorf 47 (2004), 415-430

KACZMARCZYK, E.; BOJAROJĆ-NOSOWICZ, B.; FIEDOROWICZ, A.:

Leukocyte acid phosphatase and metabolic efficiency of phagocytes in the first lactation trimester of cows from a leukaemic herd. J. Appl. Genet. 46 (2005a), 59-67

KACZMARCZYK, E.; BOJAROJĆ-NOSOWICZ B.; FIEDOROWICZ A.:

Polymorphism of blood leukocytes acid phosphatase and haematological indices during the first months after calving in cows naturally-infected with the bovine leukaemia virus. Bull. Vet. Inst. Pulawy (2005b) 49, 15-21

KACZMARCZYK, E.; TAUBE, K.:

The influence of acid phosphatase polymorphism of blood leucocytes on selected haematological and immunological indices in young cattle. Genet. Pol. 31 (1990), 245-250

KACZMARCZYK, E.; WALAWSKI, K.:

Genetic determination of acid phosphatase polymorphism of blood leucocytes in cattle. Genet. Pol. 33, (1992), 125-129

KACZMARCZYK, E.:

Studies on polymorphism of acid phosphatase in leukocytes of bovine peripheral blood. (in polish) Med. Wet. 42 (1986), 440-442

KIM, J.J.; NOTTINGHAM, L.K.; SIN, J.I.; TSAI, A.; MORRISON, L.; OH, J.; DANG, K.; HU, Y.;

KAZAHAYA, K.; BENNETT, M.; DENTCHEV, T.; WILSON, D.M.; CHALAIN, A.A.; BOYER, J.D.;

AGADJANYAN, M.G.; WEINERR, D.B.:

CD8 positive $\mathrm{T}$ cells influence antigen-specific immune responses through the expression of chemokines. J. Clin. Invest. 102 (1998), 1112-1124

MALLARD, B.A.; DEKKERS, J.C.; IRELAND, M.J.; LESLIE, K.E.; SHARIF, S.; VANKAMPEN, C.I.;

WAGTER, L.; WILKIE, B.N.:

Alteration in immune responsiveness during the peripartum period and its ramification on dairy cow and calf health. J. Dairy Sci. 81 (1998), 585-594

MILOJEVIC, Z.; RUSOV, C.; ZIVKOVIC, R.; STOJICEVIC, S.; JOJIC-MALICEVIC, L.; BOZOVIC, V.: Studies on mastitis. Somatic cells and milk chemical composition in cows with enzootic leukosis. Vet. Glasnik 45 (1991), 691-696

PUCHAJDA, Z.; CZAPLICKA, M.; WIELGOSZ, Z.; GEBLER, A.; IWAŃCZUK, K.; JÓŹWIK, R.:

The effect of genotype and breeding conditions on milk yield and composition (in polish). Acta Acad. Agricult. Tech. Olst. 38 (1993), 5-14

RUSOV, C.; MILOJEVIC, Z.; STOJANOVIC, L.:

Occurrence of mastitis and sanitary-hygienic quality of milk of cows infected with enzootic leukosis. Vet. Glasnik 48 (1994), 303-308

SAWA, A.; PIWCZYŃSKI, D.:

Somatic cell count and milk yield and composition in Black and White x Holstein-Friesian cows. (in polish) Med. Wet. 58 (2002), 638-640 
SCHEPPERS, A.J.; LAM, T.J.G.M.; SCHUKKEN, Y.H.; WILMINK, J.B.M.; HANEKAMP, W.J.A.:

Estimation of variance components for somatic cell counts to determine thresholds for uninfected quartes. J. Dairy Sci. 80 (1997), 1033-1040

SHAFER-WEAVER, K.A.; PIGHETTI, G.M.; SORDILLO, L.M.:

Diminished mammary gland lymphocyte functions parallel shifts in trafficking patterns during the postpartum period. Proc. Soc. Exp. Biol. Med. 212 (1996), 271-279

SORDILLO, L.M.; GIGHETTI, G.M.; DAVIS, M.R.:

Enhanced production of bovine tumor necrosis factor- $\alpha$ during the periparturient period. Vet. Immunol. Immunopathol. 49 (1995), 263-270

STONE, D.M.; HOF, A.J.; DAVIS, W.C.:

Up-regulation of IL-2 receptor $\alpha$ and MHC class II expression on lymphocyte subpopulations from bovine leukemia virus infected lymphocytotic cows. Vet. Immunol. Immunopathol. 48 (1995), 65-76

STOTT, M.L.; THURMOND, M.C.; DUNN, S.J.; OSBURN, B.I.; STOTT, L.: Integrated bovine leukosis proviral DNA in T helper and T cytotoxic/suppressor lymphocytes. J. Gen. Virol. 72 (1991), 307-315

TIZARD, I.:

Veterinary immunology an introduction. Ed.: W. B. Saunders (Philadelphia PA) 1992, 72-84

WELLENBERG, G.J.; VAN DER POEL, W.H.M.; VAN OIRSCHOT, J.T.:

Viral infection and bovine mastitis: a review. Vet. Microbiol. 88 (2002), 27-45

WU, D.; TAKAHASHI, K.; LIU, N.; KOGUCHI, A.; MAKARA, M.; SASAKI, J.; GORY OKADA, K.:

Distribution of T-lymphocyte subpopulation in blood and spleen normal cattle and cattle with enzootic bovine leukosis. J. Comp. Pathol. 120 (1999), 117-127

YOSHIKAWA, H.; XIE, B.; OYAMADA, T.; HIRAGA, A.; YOSHIKAWA, T.:

Detection of bovine leukemia viruses (BLV) in mammary tissues of BLV antibody-positive cows affected by subclinical mastitis. J. Vet. Med. Sci. 59 (1997), 301-302

Received: 2005-01-19

Accepted: 2005-10-10

Corresponding author

Dr. habil. EWA KACZMARCZYK

University of Warmia and Mazury in Olsztyn,

Department of Animal Genetics,

ul. Oczapowskiego 5, 10-719 Olsztyn,

Poland

E-mail: ewagen@moskit.uwm.edu.pl 